DOI: $10.15290 / \mathrm{bsp} .2017 .22 .03 .12$

Maria Cudowska

Uniwersytet w Białymstoku

mcudowska@wp.pl

\title{
Child Custody in Minnesota and in Poland. The Best Interest Factors - A Comparative Overview
}

\author{
Sprawowanie opieki nad dzieckiem w stanie Minesota i w Polsce. \\ Koncepcja "nadrzędnego interesu dziecka" - analiza porównawcza
}

\begin{abstract}
In an era of shaky familial relations, child custody and the principles of the best interest of the child have emerged with more strength and fortified protections than ever before. With the growing divorce rates, children remain the most vulnerable parties, thereby making them prone to some of the more damaging consequences of family dissolution. When analyzing child custody/protection laws around the globe, there are clear differences as to the enactment and enforcement of certain protections for children. This paper will explore the differences and similarities between Poland and the United States' (specifically, Minnesota) best interest factors. Additionally, this paper will aim to find a common ground between the common law and civil law regulations in place in both Minnesota and Poland.
\end{abstract}

Keywords: child custody, best interest factors, family law, domestic violence

Słowa kluczowe: opieka nad dzieckiem, zasada nadrzędnego dobra, ochrona dziecka, przemoc domowa

\section{Introduction}

The prevailing 'best interest' of the child standard has been ever-present at both the domestic and international levels ${ }^{1}$. In Poland, matters relating to child custody are reviewed and ruled on based on a 'wellbeing of the child' standard; in the United States, this standard is termed the 'best interest of the child' standard'. Although

1 See D.M. Blair, M.H. Weiner, Resolving Parental Custody Disputes - A Comparative Exploration, „Family L.Q." 2005, vol. 39, s. 247.

2 W. Stojanowska, Dobro dziecka w aspekcie sprawowanej nad nim władzy rodzicielskiej, „Studia nad Rodziną" 2000, vol. 4 nr 1(6), s. 55. 
this standard is termed differently around the world (as is the case between Poland and Minnesota), the meaning and effectuation of the standard vary. For example, the 'wellbeing of the child' standard in Poland is not only in place to protect children; rather, its purpose is twofold - the Polish 'standard' also refers to a wider concept of public policy ${ }^{3}$. The law governing children and their best interests is widespread in national legislatures throughout the world. That stated, one of the most significant international conventions, namely, the Convention on the Rights of the Child (hereinafter referred to as 'Convention') $)^{4}$, leaves several of the world's most powerful countries unbound by its provisions.

In fact, it may be shocking to readers that one of the most established countries in the world, the United States, is one of the many countries that is not subject to the Convention's provisions. As will be discussed in greater detail in this paper's later sections, it remains uncertain as to how international conventions, such as the Convention, can be effective and actually take certain protective actions afforded under the conventions' terms. To clarify, although the United States signed the Convention on February 16, 1995, it has not been ratified due to the fact that some States wished to execute minors; and even though the Supreme Court held in 2005 that it is unconstitutional for state governments to execute minors, the Convention remains unratified. It goes without saying that the wellbeing and best interests of a child are one of the pillars of society; therefore, it is imperative that these protections are compared and contrasted on a global scale, hence this paper's comparison between Poland and Minnesota. Recently, there have been changes made to Minnesota's family laws, which in turn, has led to well-developed and extremely detailed statutes protecting the 'best interest' of the child. Unlike Minnesota's newly enacted laws, Polish family law has been an ever-evolving legal system that has ultimately led to broader statutory language - because of this, Poland's family laws related to child custody will never be as specific, or as detailed, as the laws in Minnesota. The article offers a brief summary, in a comparative nature, of some of the major issues concerning the best interest factors.

\section{Overview}

Over the years, history has reflected a continuous change-of-approach system governing familial law matters, especially those including children. The time of the Blackstonian view has lapsed, as the number of unmarried couples increased largely since the 1990s. Considering the various changes over the years, many are in

3 The concept of public policy, in Polish „, zasady współżycia społecznego," is a common concept in civil law, and a general clause in the Polish law.

4 UN General Assembly, Convention on the Rights of the Child, 20 November 1989, United Nations, Treaty Series, vol. 1577, s. 3, available at: http://www.refworld.org/docid/3ae6b38f0.html (accessed 3 April 2017). 
agreement with the current view that "marriage is obsolete;" this is because it does not address all of the current challenges that have been brought to the forefront of modern American and European societies alike. When analyzing this area of law, it is important to bear in mind that adults, in the event of a divorce, can go their separate ways without any emotional or financial consequences; children, conversely, are still the most vulnerable parties because they are still tied to both parents in some form or capacity.

Due to the susceptibility of children, in determining custody issues, the pivotal rule is reviewed and ruled on based upon the 'best interest' of the child standard, as will be discussed in greater detail later in this paper. The doctrine of the 'best interest' of the child has its origins rooted in the beginning of the nineteenth century. During this timeframe, courts started to balance and analyze the rights of both parents; this was a departure from previous cases as fathers were often ruled in favor of, regardless of said decision being in the 'best interest' of the child. Although the courts have applied the 'best interest of the child' standard for many years, the courts are still facing criticism for giving leeway for, what is termed as 'unbridled judicial decisions.'

While some cases may be forthright, as a rule of thumb, the courts must take reasonable precaution when determining custody matters and issuing orders; such orders affect not only the child's future, but also the lives of every member of that particular family.

\section{An American perspective: The Uniform Marriage and Divorce Act}

First and foremost, it is important to establish that family law in the United States is not governed under the federal laws; rather, family law in America is governed based on a state-by-state basis (put another way: each state has created its own unique set of laws that govern familial law issues). This, in turn, has given each and every state great latitude in enacting the laws that govern familial matters. Nevertheless, the United States does have a 'uniform' set of laws that are meant to guide the states' law and decision-making entities; this law has great influence both at the law-making level and within the states' courts. This code is known as the Uniform Marriage and Divorce $\mathrm{Act}^{6}$ (hereinafter referred to as 'UMDA'), which was promulgated by the National Conference of Commissioners on Uniform State Laws in 1970. The UMDA, along with the American Law Institute's Principles of the Law of Family Dissolution, is primarily designed to impose more structure on child custody decisions.

The UMDA in $\$ 402$, defines the 'best interest' of a child. The Act states, in pertinent part, that in order for a court to determine custody in accordance with the best interest factors, it must first take into account: (1) the wishes of the child's parent, or

5 D.E. Abrams, N.R. Cahn, C.J. Ross, D.D. Meyer, Contemporary Family Law, Hardcover 2009, s. 675.

6 Uniform Marriage and Divorce Act, 9A U.L.A. 91 (1979). 
parents, as to the child's custody. This provision is reasonable and important; its primary focus is on the child's wishes, which is the very purpose of the UMDA. While this provision does provide vast protections for children, it is also considered controversial amongst persons in the legal field; this is because courts have struggled to determine what the proper age is for classifying someone as a 'child' when weighing the 'best interest' factors for said child (in comparison with the parents' wishes/interests) when making custody/'best interest' decisions.

Secondly, the UMDA also takes into account: (2) the wishes of the child as to his custodian. This provision seems rather contentious given that there might be bias in a Court's decision should it be made by strictly viewing it in terms of what the child wants at that moment in time. Certainly, such a decision is not made with respect to the parents' "good" and "bad" sides; therefore, the court's decision in the here and now may make the future outcome of no benefit at all to the child.

Next, the UMDA also explores (3) the interactions and interrelationships of the child with his or her parents and/or siblings, as well as any other interrelationships the child may develop over time that ultimately would affect the best interest of the child. On its face, this provision seems rather broad, as it extends the circle of persons to "any other person." For instance, the 'other person' could very well be the child's nanny; however, it is unclear how the nanny's testimony and input would be remotely relevant to determining what would be in the best interest of the child. That stated, one could argue that the 'other person' (or, for purposes of the previous example: the nanny) may know the child at a different level, or alternatively, view the child and his or her relationship with each parent in a different light than that of the parents or child.

Respectively, (4) the court should consider the child's adjustment to his home, school, and community. The UMDA also delves into the effect that will be had on the child as it relates to his or her adjustment to a new home, school, and community. It is easy to forget that, ultimately, it is the child that will be forced to adjust the most as a result of the domestic dispute, not the parents themselves. With this in mind, the UMDA affords fact finders the opportunity to critically analyze the effect that will be had on the child's ability to adjust to his or her new circumstances. This consideration is imperative on the basis that the child's adjustment ultimately shapes and molds the person he or she becomes.

Most importantly though, is the last provision (5), which focuses on the "mental and physical health of all individuals involved." This is a reasonable provision to include as it is all-inclusive in analyzing and accounting for the mental and physical capacities of the persons whom are making the decision as it relates to the child's best interest.

Lastly, the UMDA states that "the court shall not consider conduct of a proposed custodian that does not affect his relationship to the child." The inclusion of such a provision is interesting in that it asks the courts, and ultimately the American legal 
system, to analyze, reconcile, rule open, and ultimately issue orders regarding child custody, yet the broad factors laid out above leave much to the court's discretion; more often than not, the "answer" is not clear-cut. One must ask him or herself, "is this truly the most effective method for determining what is in fact in the best interest of the child?". Interestingly enough, the fact that courts are expected to issue custody orders that are safe for children, but needless to say the reconciliation of the competing factors is not always clear cut ${ }^{7}$. It was not until recently that Congress enacted victim-parent safety laws that are in place to secure the child's right to not be placed in the custody of a parent who has committed domestic violence ${ }^{8}$.

In any event, the process of determining child custody is a fact-intensive inquiry that requires the court to weigh and balance the aforementioned factors and, in doing so, the court must determine, based on the facts, whether it is in favor or opposed regarding the child's custody as between the competing parties ${ }^{9}$.

\section{Polish perspective}

For some time, Polish scholars have discussed and debated the definition of the 'wellbeing of the child' standard and what protections it actually affords children; this can be said as Polish law still does not have a comprehensive statutory definition of the standard. One of the definitions, adopted nearly 27 years ago, explains the wellbeing of the child standard as follows:

The term 'wellbeing' of the child in the context of family law has to be understood as a complex of values of a tangible and intangible nature, essential to the proper physical and emotional development of the child, as well as proper preparation for work adequately to child's skills, whereby these values are determined by various factors, and the structure of these factors depends on the subject matter of the legal standard, and the situation that the child is currently in, and the concurrence between the abovementioned wellbeing of the child and the public interest." ${ }^{10}$

Art. 3 of the Convention on the Rights of the Child provides for a more concise, but stillample, definition:

7 A.M. Bailey, Prioritizin Child Safety as the Prime Best - Interest Factor, „FamLQ”, vol. 47, s. 35.

8 Ibidem.

9 See Hains v. Hains, 36 So. 3d 289, (La. Ct. App. 1st Cir. 2010); Raleigh v. Watkins, 97 Mich. App. 258, 293 N.W.2d 789 (1980) (The "best interest of the child" test of Child Custody Act is highly subjective and individualized.); Gaskill v. Gaskill, 936 S.W.2d 626 (Tenn. Ct. App. 1996).

10 W. Stojanowska, Dobro dziecka w aspekcie sprawowanej nad nim władzy rodzicielskiej, „Studia nad Rodziną" 2000, 4/1, (6), s. 63, available at: http://bazhum.muzhp.pl/media//files/Studia_nad_Rodzina/Studia_nad_Rodzina-r2000-t4-n1_(6)/Studia_nad_Rodzina-r2000-t4-n1_(6)-s55-65/Studia_nad_Rodzina-r2000-t4-n1_(6)-s55-65.pdf, entrance on 02.03.2017. 
"In all actions concerning children, whether undertaken by public or private social welfare institutions, courts of law, administrative authorities or legislative bodies, the best interests of the child shall be a primary consideration"11.

These definitions are not meant to be considered as an exhaustive list; rather, it is meant to give a perspective of what the best interest of the child is and, further, what are some of the factors securing children.

Considering the above, bear in mind that Poland, as a member of the European Union, is not only bound by its national laws, but it is also bound by both EU law and several international Conventions that relate to children. Given these facts, it is evident that the legal spectrum, as it relates to child protection, is very broad. $\mathrm{Ne}$ vertheless, the principal Polish law regulating parental responsibilities, in relation to children, stems from the Polish Constitution of April 2, $1997^{12}$.

The Constitution, in Art. $48 \mathrm{sec} .1$, states that 'parents have the right to rear children in accordance with their own convictions...' Also, Art. $48 \mathrm{sec} .2$ permits the limitation or deprivation of parental rights only as specified by statute, or on the basis of a final court judgment ${ }^{13}$. The idea of parental authority and the role of the parents in all family matters is further regulated in the statute of February 25, 1964 - The Polish Family and Guardianship Code (Kodeks rodzinny i opiekuńczy) ${ }^{14}$.

Pursuant to the Polish Family and Guardianship Code the child remains under the authority of both parents and, in exceptional cases, by both of the parents ${ }^{15}$. More importantly, however, it needs to be highlighted that the custody over the child's person and property are paramount as it relates to parental authority. In the event of a divorce, an appropriate authority, such as the court, is obliged to safeguard the child's best interest and wellbeing no matter the parents' personal positions in the domestic dispute.

In order to achieve this goal, the court may consider, for instance, whether the parents expressed violent behavior towards one another and, if so, how that may affect the child's wellbeing. This is just one of various considerations a presiding court must engage in before making a determination regarding a child's custody. Unfortunately these factors do not have any legal significance whatsoever ${ }^{16}$.

11 UN General Assembly, Convention on the Rights of the Child, „United Nations, Treaty Series” 20 November 1989, vol. 1577, s. 3, available at: http://www.refworld.org/docid/3ae6b38fo.html (accessed 3 April 2017), Art. 3.

12 Constitution of the Republic of Poland dated 2 April 1997, (Journal of Laws of 1997, No. 78, item 483 as amended).

13 Ibidem.

14 Family and Guardianship Code dated 25 February 1964, (Journal of Laws of 1964, No. 9, item 59 as amended).

15 A. Mączyński, J. Mączyńska, National Rerport: Poland, available at: http://ceflonline.net/wp-content/uploads/Poland-Parental-Responsibilities.pdf, s. 1.

16 Ibidem. 
Moreover, in Polish law, there are two kinds of legal rules that can be applied in custody cases, in determining the best interest factors:

a) Rules that determine the way in which an authority will implement the law, limiting the authority only to take into consideration the wellbeing of the child.

b) Rules that precisely instruct the authority how to safeguard and protect the best interest of the child ${ }^{17}$.

To exemplify, the more recent cases take into consideration how the best interest factors deal with transnational marriages. In the case of Nadolska and Bronek Nadolska, Lopez v. Poland ${ }^{18}$, the applicants alleged a breach of Article 8 of the Hague Convention $^{19}$ in that the Polish court's ordering of Ms. Nadolska's son to return to Mexico was contrary to his best interest because the separation from his mother would cause him irreparable and serious psychological harm. The Court eventually ruled that the applicants did not exhaust the national measures available to them, yet it is still popular for the applicants to invoke the best interest principles.

\section{Child custody in Minnesota. Definition of the best interest factors}

In America, the states have different understandings of laws when it comes to defining the best interest factors. As of August 1, 2015, the Minnesota child custody laws have been significantly changed, and commentators have highlighted that it might be one of the biggest changes in the last decade, while others categorize it as a once-in-a-generation type change for protecting a child's interest ${ }^{20}$. For many practitioners, this has been an unique moment in history considering the fact that the statutory factors governing virtually all custody and parenting time decisions, known as the "best interest factors," have been completely overhauled"

One of the primary reasons for Minnesota's overhaul of its child custody laws was because it needed to adjust to 21 st century realities, that is to state that the Minnesota legislature determined it needed to figure out a compromise between shared parenting time and case-specific decision-making. The M.S.A $₫ 518.17$, effective

17 http://bazhum.muzhp.pl/media//files/Studia_nad_Rodzina/Studia_nad_Rodzina-r2000-t4-n1_ (6)/Studia_nad_Rodzina-r2000-t4-n1_(6)-s55-65/Studia_nad_Rodzina-r2000-t4-n1_(6)-s55-65. pdf.

18 Application no. 78296/11 Karolina NADOLSKA and Bronek LOPEZ NADOLSKA against Poland.

19 Hague Conference on Private International Law, Hague Convention on the Protection of Children and Co-operation in Respect of Intercountry Adoption, 29 May 1993, 33, available at: http://www. refworld.org/docid/3ddcb1794.html (accessed 3 April 2017).

20 M.P. Boulette, A Practioner's Guide To Minnesota's New Best Interest Factors, 9 Wm. Mitchell J. L. \&Prac. s. 1.

21 MINN. STAT. \$518.17, subdiv. 1-2 (2016); MINN. STAT. \$257.025; but c.f. MINN. STAT. \$257C.04 (defining a child's best interest in third-party custody matters). 
from August 1, 2015, Subdivision 1 enumerates 12 best interest factors of the child, which are discussed in greater detail below.

First, (1) "a child's physical, emotional, cultural, spiritual, and other needs, and the effect of the proposed arrangements on the child's needs and development," shall be taken into account. This is a very detailed provision, as it enumerates not only physical, emotional needs, but it also accounts for the effect that it may have on the child. In contrast, the UMDA does not enlist the needs of the child in such great detail; rather, it instead labels it as the child's "wishes." Most importantly, however, neither of these statutes mention, nor do either take into consideration, the wishes of the parents. Nonetheless, it seems rather controversial as to whom is qualified to determine what is best for the child, both on an emotional and physical level. Moreover, there has been great dispute as to whether there is or should be an age threshold that should be applied when assessing such matters.

The second provision calls for: (2) "any special medical, mental health, or educational needs that the child may have that may require special parenting arrangements or access to recommended services." While Minnesota should be commended for looking at these specific topics when making child custody decisions, it is puzzling that the legislature limited and narrowly defined specific factors for a court to use in rendering its decision.

The third provision is: (3) the "reasonable preference of the child, if the court deems the child to be of sufficient ability, age, and maturity to express an independent, reliable preference." Here, The intention of the drafters must have been to make this provision very detailed in order to avoid confusion amongst the courts and lay people. However, one must question the legislature's decision to use the reasonableness of the child's preference, as such a factor leaves room for discussion and interpretation amongst the court and interested parties to the custody battle. Again, the sufficient age and maturity may vary from case to case, which in turn, may cause confusion and cause injustice.

Provision four raises the issue of domestic abuse: (4) "whether domestic abuse, as defined in section 518B.01, has occurred in the parents' or either parent's household or relationship; the nature and context of the domestic abuse; and the implications of the domestic abuse for parenting and for the child's safety, well-being, and developmental needs." Notwithstanding the fact that domestic violence should be condemned under all circumstances, provision number 4 states that the nature and context of the abuse has to be investigated when assessing the child's best interests.

Provision (4) seems to indicate that some sort of investigation needs to be held in order to establish the circumstances under which the domestic violence occurred and the history surrounding such occurrence(s). Should an investigation reveal that it has happened only once, a court would have to consider this fact and determine its impact on custody; however, there is a compelling argument that even such consideration would result in a violation of making a decision in the child's best interest. 
Also, there is no indication that, for instance, psychological violence should be treated the same way as domestic violence. Under the UMDA, only the interactions and interrelationships have to be investigated, and this seems sufficient.

The Minnesota statute in provision (5) addresses the issue of "physical, mental or chemical health issue of a parent that affects the child's safety or developmental needs." It goes without question that this provision is calling for a full disclosure of a parent's overall health condition and any other drug related issues he or she may have, which may end up in an order for a release of medical records. However, it is controversial if all medical records should be deemed relevant and whether certain records should be considered although the parent has made significant changes over a long period of time. For instance, medical records that are very old and may not adequately reflect the parent's capabilities as a responsible parent that may provide the best situation for the child, even though the parent has a checkered past.

Provision (6) deals with the "history and nature of each parent's participation in providing care for the child." What is interesting with this provision is that there is no mention of the primary caretaker and, this in turn, allows the courts to be very flexible as it pertains to which parent is best-suited for providing the child with the best set of circumstances, both at present and in the future. It is important to note that the UMDA does not address the "history and nature" of each parent's participation at all.

Provision (7) deals with the "willingness and ability of each parent to provide ongoing care for the child: to meet the child's ongoing developmental, emotional, spiritual, and cultural needs; and to maintain consistency and follow through with parenting time, which can be summarized into a conclusion that dedication matters".

Provision (8) takes into account "the effect on the child's well-being and development of changes to home, school, and community" - which means that the parent who is seeking custody, and lives in another state, will always have a weaker argument in court. Nevertheless the courts will consider the quality and location of the school as a best interest factor. The court in Schultz v. Ruff (Minn. Ct. App. 2015) held that: " ' $\mathrm{t}$ ] he best interests of the child' means all relevant factors to be considered and evaluated by the court," including 12 specific factors identified in the statute. Minn. Stat. $\$$ 518.17, subd. 1(a) (2014). The parties stipulated to consideration of criteria related to school quality, and the only criterion found by the district court to favor Otsego, was the wider range of diversified programming offered, which was relevant to the children's best interests. The district court considered location as related to the logistics of getting the children to school, which also was relevant to their best interests."

Provision (9) talks about "the effect of the proposed arrangements on the ongoing relationships between the child and each parent, siblings, and other significant persons in the child's life," and is very similar to provision (3) of the UMDA. However it speaks just of relationships, not "interactions and interrelationships".

Provision (10) calls for "the benefit to the child in maximizing parenting time with both parents and the detriment to the child in limiting parenting time with 
either parent". It seems that the core of this provision is to put emphasis on shared time parenting agreements, which without a doubt is to the benefit of the child.

(11) Except in cases in which domestic abuse as described in clause (4) has occurred, the disposition of each parent to support the child's relationship with the other parent and to encourage and permit frequent and continuing contact between the child and the other parent.

Lastly, the statute considers (12) the willingness and ability of parents to cooperate in the rearing of their child; to maximize sharing information and minimize exposure of the child to parental conflict; and to utilize methods for resolving disputes regarding any major decision concerning the life of the child. A court may award sole custody to one parent, when the parent are unable to cooperate in the rearing of the child. The court in Rexine v. Rexine 2015 WL 6442560 (Min. Ct. Appeals 2016) found, that "evidence supports an award of sole legal custody to [Rexine]" because the record showed that Bulisco would use sole legal custody to "continue to control [Rexine's] parenting time to the degree that would alienate [Rexine] from his children."

\section{Conclusion}

The Minnesota statute provides for a broad, and very detailed understanding of what the best interest of the child really is. While it is crucial for the court to grant a fair and just custody order, circumstances may vary, and the judicial system is still facing a great challenge in providing equitable judgements. In any event, the process of determining child custody is an extremely fact-intensive inquiry that requires the court to weigh and balance numerous factors and, in doing so, the court must determine, based on the facts, whether it is in favor or opposed regarding the child's custody as between the competing parties. As Polish law still does not have a comprehensive statutory definition of the best interest standard, it has to be considered how and when should necessary changes take place. Minnesota has adjusted its custody laws to the 21 st century standards and so should Poland. Most importantly however, federal as well as Minnesotan victim-parent safety laws guarantee that a child will not be placed in custody with a parent that has committed domestic violence, and perhaps Polish policy-makers could look up to already established and effective provisions.

\section{BIBLIOGRAFIA}

Abrams D.E., Cahn N.R., Ross C.J., Meyer D.D., Contemporary Family Law, Hardcover 2009. Application no. 78296/11 Karolina NADOLSKA and Bronek LOPEZ NADOLSKA against Poland. Bailey A.M., Prioritizin Child Safety as the Prime Best - Interest Factor, "FamLQ” vol. 47. 
Blair D.M., Weiner M.H., Resolving Parental Custody Disputes - A Comparative Exploration, "Family L.Q." 2005, vol. 39.

Boulette M.P., A Practioner's Guide To Minnesota's New Best Interest Factors, 9 Wm. Mitchell J. L. \& Prac.

Gaskill v. Gaskill, 936 S.W.2d 626 (Tenn. Ct. App. 1996).

Hague Conference on Private International Law, Hague Convention on the Protection of Children and Co-operation in Respect of Intercountry Adoption, 29 May 1993.

Hains v. Hains, 36 So. 3d 289, (La. Ct. App. 1st Cir. 2010).

Mączyński A., Mączyńska J., National Rerport: Poland, available at: http://ceflonline.net/wp-content/ uploads/Poland-Parental-Responsibilities.pdf.

MINN. STAT. $\$ 518.17,(2016)$.

Raleigh v. Watkins, 97 Mich. App. 258, 293 N.W.2d 789 (1980).

Rexine v. Rexine 2015 WL 6442560 (Min. Ct. Appeals 2016).

Stojanowska W., Dobro dziecka w aspekcie sprawowanej nad nim władzy rodzicielskiej, "Studia nad Rodziną" 2000, 4 no 1(6).

UN General Assembly, Convention on the Rights of the Child, 20 November 1989, United Nations, Treaty Series, vol. 1577.

Uniform Marriage and Divorce Act, 9A U.L.A. 91 (1979). 
